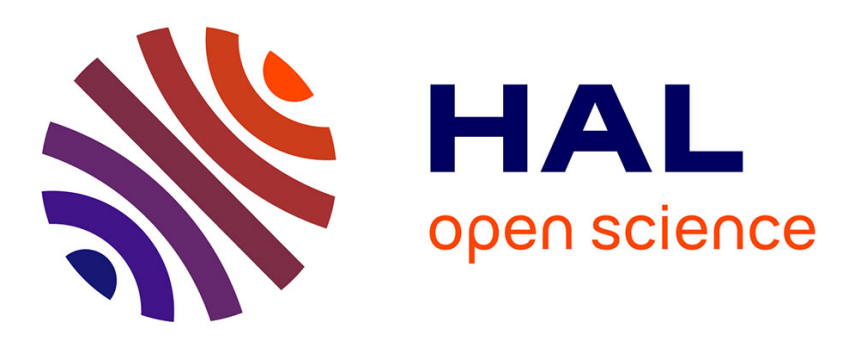

\title{
Vernacular science knowledge: its role in everyday life communication
}

Wolfgang Wagner

\section{To cite this version:}

Wolfgang Wagner. Vernacular science knowledge: its role in everyday life communication. Public Understanding of Science, 2007, 16 (1), pp.7-22. 10.1177/0963662506071785 . hal-00571117

\section{HAL Id: hal-00571117 \\ https://hal.science/hal-00571117}

Submitted on 1 Mar 2011

HAL is a multi-disciplinary open access archive for the deposit and dissemination of scientific research documents, whether they are published or not. The documents may come from teaching and research institutions in France or abroad, or from public or private research centers.
L'archive ouverte pluridisciplinaire HAL, est destinée au dépôt et à la diffusion de documents scientifiques de niveau recherche, publiés ou non, émanant des établissements d'enseignement et de recherche français ou étrangers, des laboratoires publics ou privés. 


\title{
Vernacular science knowledge: its role in everyday life communication
}

\author{
Wolfgang Wagner
}

This paper argues that our understanding of how the public understands science is incomplete as long as we do not answer the question of why, under which conditions, and in which form the general public assimilate scientific background knowledge. Everyday life and communication are governed by criteria of social efficiency and evidence. Under the conditions of everyday life, it is sufficient for the lay person to possess and employ metaphoric and iconic representations of scientific facts-called "vernacular science knowledge" - that are wrong in scientific terms, as long as they are able to serve as acceptable and legitimate belief systems in discourses with other lay people. These representations are tools for a purpose that follow local rules of communication. Research within the framework of Social Representation Theory-collective symbolic coping with biotechnology in Europe, lay understanding of sexual conception, as well as traditional versus modern psychiatric knowledge in India-is presented to illustrate.

\section{Introduction}

The European Union, amongst other institutions and countries, strives to develop a so-called knowledge-based society as formulated in the Lisbon Agenda in March 2000. This strategic goal was set for Europe for 2010. A knowledge-based society is supposed to integrate all instruments available for knowledge acquisition in a scheme that is accessible to all members of society to easily locate scientific evidence to inform their political, business and other decisions. Scientific knowledge is supposed to permeate all of society's realms and, in the ideal case, also to inform everyday life and personal conversations. In the light of this ambitious agenda, it may be worthwhile to examine some aspects of knowledge that circulates in everyday life, the criteria of evidence governing everyday social life, and the role scientific knowledge may play in the vernacular realm. In the context of publics and science, this focus has consequences for education, governance and technological regulation. Different sections of the public are likely to hold divergent versions of vernacular science knowledge that determine the success or failure of tertiary education and the publics' reaction to technological change. The issue of different publics and their knowledge background constitutes a challenge to the ideas of what a knowledge society can and should be in the modern world. 


\section{Everyday life, criteria for everyday knowledge, and communication}

\section{Everyday life and common sense}

Everyday life engulfs all of us to varying degrees. It encompasses the ordinary and extraordinary life occurrences experienced by members of society and in their different life stages. It is "the day-to-day sequence of events to which the member of society is subjected here and now in view of obligations to do with career, family, free time, and others" (Matthes and Schütze, 1981: 22). Everyday life, hence, is the routine, working day life of the majority of people and the sphere of natural, spontaneous, unconsidered, everyday experience and thought. It stands in contrast to the extraordinary, public and professional life that is the sphere of considered, artificial, non-spontaneous, and in particular also scientific experience and thought (Elias, 1978: 26).

In their lifetime, people acquire knowledge and ways of thinking about mundane, symbolic and esoteric facts that constitute common sense. One includes in everyday knowledge the elements of the social supply of knowledge which everybody receives in his or her childhood in a "natural" way and as a matter of routine (Sprondel, 1979). This knowledge is in principle accessible to everyone, even if the elements differ in content in diverse cultures, societies, and subcultures. Everyday thinking - and common sense, for that matter-is the faculty of unquestioned and spontaneous judgments:

When we say that someone has common sense, that is not only supposed to mean that they use their eyes and ears, but that they keep them open, as it were, and use them meaningfully, intelligently, and in a way conducive to forming opinion and reflection, or at least attempt it, and that they are in a position to deal with everyday problems in an everyday manner with a degree of efficiency. (Geertz, 1983: 264)

It includes the perception of factuality as is nicely expressed by the German verb for perception, i.e. "wahrnehmen," which literally means, "to take for real."

In addition, everyday knowledge is continuously complemented by knowledge about technology and science as it becomes common and available in historical and societal development (Bangerter, 1995; Moscovici, 1992). There are, however, social constraints that link social positions and opportunities for knowledge acquisition such as society's hierarchical processes of stratification that have institutionalized the split of social knowledge into everyday and specialized. Both sorts of knowledge differ not only according to the places, roles, institutions and organizations in which they are thought and applied, but above all according to the nature of knowledge acquisition. While acquiring common sense is necessary for everybody to count as a competent member of a culture and society, acquiring special knowledge is linked to social preconditions: occupation of particular roles and expert nature. Even though in democratic societies people have free physical access to the literature of university libraries, it remains closed to most in actual fact, since it does not depend so much on the specific content that one would like to acquire, but rather on the possession of the methodological thought patterns and capacities, that is, scientific literacy, required for acquisition which are imparted at special institutions.

Being the central mental faculty, everyday thinking and common sense serve distinct purposes and are shaped by pragmatic criteria that set them apart from professional and specialized ways of thinking and acting. Everyday cognition must be sufficient to satisfy the practical interests, which are the center of attention at any time of everyday life, where the most basic requirement is not satisfying any philosophical or scientific criterion of validity, but safeguarding social survival.

Social survival depends on the approximate social suitability and correctness of action. 
Other than in physical survival, where a wrong action may be lethal, acts of social survival are repeatable, changeable, indeed retractable, as for example by apology. Most of the time, there is not just one path of action to safeguard social survival. The fuzziness of social situations and complexity of contexts make actions achieve their aim more or less successfully in many different ways that can range from adaptation to actively shaping social conditions, albeit often in a "muddling through" style (March and Olson, 1986). Accordingly, we can identify three characteristics and criteria for everyday thinking and acting: being affected, the imperative to act, and situatedness (Wagner and Hayes, 2005).

Being affected means that whatever a person does has immediate consequences for him or herself and affects the well-being and status of others as well. People depend directly on what is going on in their environment and their immediate reactions to them. This "beingdirectly-affected" by their dealings entails that perception and thought always occur in the context of action in everyday life. Everyday acting is about the sense of identity and social survival of the actors themselves.

Second, people in everyday situations see themselves constantly confronted by the necessity of taking action: repairing the roof of their house, connecting up a recently bought stereo system, or managing an encounter with other people. Action based on clear and strongly held knowledge is more likely to be effective than hesitation triggered by uncertainty and half-hearted opinions and attitudes. Both, everyday acting, to the extent that it is not routine, and affectedness demand an "unequivocal behavior orientation" (Jones and Gerard, 1967). As a pragmatic orientation, hence, it is better to act on the basis of faulty and potentially incomplete knowledge than not at all. A cognitive side effect of the action imperative is the tendency by people to extremize their attitudes and increase confidence associated with them whenever a related action comes up (Wagner and Gerard, 1983). Despite its "logical faultiness," this way of thinking works surprisingly well in everyday contexts.

Finally, everyday thinking and acting is always situated in a social setting. It is the persons present, the temporal and local frame of the situation, and the task at hand that determine the expectations of the people as to what action may be required. This multitude of possible combinations and situation constraints constitutes the arena of everyday knowledge, thinking and acting.

The pragmatic imperative implied by being affected, the need to act and the complexity of situations shapes the processes of everyday thinking and, as a consequence, also the character of knowledge associated with it. Everyday thinking is heavily leaning towards concrete instead of abstract information; similarity, metaphor and analogy are the preferred cognitive tools of inference; people hardly escape their desire for attributing causes to events; and the desire and need to communicate with others is at the heart of everyday behavior (cf. Wagner and Hayes, 2005, for a review). It is not hard to see that this has repercussions on the structure and forms of scientific knowledge that people may be willing or required to assimilate.

\section{Reasons for acquiring science knowledge}

Grass-root movements and non-governmental initiatives increasingly challenge modern society's reliance on and development of new and complex technologies. This opposition gave rise to a great number of studies aimed at establishing the determinants of the public's attitudes towards science and technology, resulting in two competing approaches: the deficit model predicting a positive relationship between the level of scientific textbook knowledge and supportive attitudes (cf. Durant et al., 1989), and the contextual model emphasizing the 
complex interdependence between science knowledge, political knowledge and political orientation, social trust and institutional patronage of the technology sector-each acting as a moderator on the others - on one hand, and supportive attitudes on the other (e.g. Irwin and Wynne, 1996; Sturgis and Allum, 2004, for a discussion and attempt at integration). The latter approach seems to come closer to modeling the forms and functions of everyday science knowledge than the former, even though it does not tackle the question: How and for what purpose does or should the man or woman on the street attain scientific-technological knowledge in the first place?

This seems to be a trite question to ask. Don't we attain this kind of knowledge in school, as it is the main constituent of school curricula and of adult education? This is definitely true, but there must be further motivations involved, particularly when it comes to life-long, adult and self-governed education in a rapidly developing world of science and technology. In 2005, a surprising number of people across Europe-62 percent-answered that they take an interest in science and technology and a hefty 44 percent say they discuss science and technology sometimes or often (Gaskell et al., 2006). These figures are likely to reflect many divergent motivations that can fall in any of the following categories.

First of all, one of the reasons seems to be the need to operate quite complex daily appliances such as cars, television sets, microwave ovens, mobile telephones, and iPods, you name it. Their handling requires a certain degree of technological sophistication. Lacking this, at least their manuals require sophisticated abilities to read between the lines. The technological background knowledge to operate these appliances, however, does not require scientific representations of how their innards work. They can be used and operated with an adequate operational knowledge that is similar in structure to cooking recipes: first, check that light, then do this, etc. Successful management of home heating systems, for example, does not presuppose any knowledge of heat radiation processes and is largely independent of whether the person knows how temperature feedback loops work (Kempton, 1986). Hence, operating technical gadgets does not constitute sufficient reason for attaining scientific textbook knowledge.

Second, there is the intrinsic interest in what is going on in the world of science and technology. This motivation may be true for some people, particularly if they are initiated experts in one or the other field of scientific inquiry and technological construction. The extent to which this intrinsic motivation for learning science exists among the majority is an open question.

Third, the motivation to develop ideas and attain knowledge about new developments might be a feeling of anxiousness with, or fear of unfamiliarity that can be resolved by learning and familiarizing oneself with the new phenomenon (Moscovici, 1984).

Fourth, there is the social value of scientific, literary, political and other knowledge as a resource of symbolic power in the social world (Bourdieu, 1979). The place where this resource is being used is in the field of communication with relatives, acquaintances and strangers, which brings us to the next and highly related point.

Fifth, the most mundane, but perhaps the most dominant motivation for people to stay somehow connected to science issues is related to their participation in the web of generalized social exchange and discourse. A series of studies investigating the places, activities and persons that appear in a sample of Austrians' diaries shows a multitude of everyday situations and tasks (Brandstätter et al., 1984; Kirchler, 1989). These range from housekeeping, securing daily income and financial "survival," conversations to communication and contact with others. On average, respondents indicated that they are engaged in conversations about 4.7 hours, reading books and newspapers about 53 minutes and watching television 1.5 hours per day. ${ }^{1}$ The large proportion of time spent conversing with 
others emphasizes the importance that self-representation, influencing other people, entertainment or simply the pleasure that can arise from social contact can play in everyday life.

Communication, either passive when reading newspapers or watching television, or active in personal conversations, presupposes shared background knowledge about personal and about societal issues. Lack of knowledge puts conversation partners in a highly unpleasant situation because it excludes them from taking part in the pleasure created by communication and sharing ideas. Hence, exhibiting ignorance in a situation of communicative exchange is likely to lead to social "punishment" and exclusion, a condition that is not only embarrassing but also painful for most people. This makes sharing knowledge and negotiating its details a function of communication (Guerin, 1997, 2001). Besides, a person's ignorance also paves the way for others exerting their symbolic power of knowing something that others don't know (cf. Bourdieu, 1979). This argument is valid for all kinds of knowledge, including knowledge about scientific and technological issues. The mundane communication situations in everyday life-be they serious or entertaining-presuppose participants that are by and large competent in shared knowledge, but not experts in science and technology "proper."

The following research examples were conducted using Social Representation Theory as a framework. This social psychological approach to societal phenomena asserts that social representations and their objects are collectively elaborated by a community "for the purpose of behaving and communicating" (Moscovici, 1963: 251). It originated in French work on "vulgarisation de la science" (Bauer, 1993) and it understands popular science knowledge as a core domain of modern common sense (Wagner and Hayes, 2005). Right from its inception, the theory put mass media and their audience's related styles of reporting on its research agenda. By straddling the individual-collective divide and by its focus on communication processes, the approach is particularly well-suited as a general framework for studying the multifarious relationship between the domain of science production and the patterns of popular understanding of science.

\section{Collective symbolic coping with new science and technology}

\section{The arrival of genetic engineering}

The aforementioned conditions of everyday life and communication as well as the validity criteria of everyday reasoning, hence, govern how people cope with and assimilate new knowledge about innovations in the scientific and technological realm. Let's leave aside the minority of highly educated and highly motivated section of the public that might read the relevant columns in newspapers or consult professional literature on a novel issue in order to attain a more accurate understanding by scientific standards. The majority of people do not have the necessary educational resources or the necessary time for such research. Nevertheless, this majority is able to converse with other people, to follow media reports to varying degrees and to use household technology.

We investigated the process of how people attain their everyday understanding and what form this understanding takes in a longitudinal and cross-sectional study of biotechnology's reception in Europe (Bauer and Gaskell, 2002; Gaskell and Bauer, 2001; Wagner et al., 2002). On the basis of this research, we suggest the general public adopt images or representations, which are the product of a collective process of "symbolic 
coping" with something novel and a component of everyday thinking and common sense. The process by which individuals come to render new technologies or scientific achievements intelligible is driven by inter-individual and mass-media communication, and results in milieu-specific imaginations that allow a reasonable level of understanding.

We structure this process into stages. First, for initiating collective symbolic coping, the new phenomenon must appear on the societal agenda as being relevant and as challenging the taken for granted or desirable way of life (cf. Gamson and Modigliani, 1989). Second, to accommodate the new phenomenon within the existing repertoires of social knowledge, various interpretations, images and metaphors emerge in media and personal discourse, which frame it and render it intelligible. These interpretations tend to settle and converge towards one, or a few fairly widely shared interpretations, which capture some of the phenomenon's essential attributes in images and beliefs in accordance with the local culture's frames of reference. Finally, in the post-coping stage, the interpretations may consolidate or give way to a more scientifically accurate understanding in the long run. Consolidation, on one hand, may occur as so-called "cultivation," where media reports keep some particular interpretation of a phenomenon alive (e.g. Bauer, 2002; Morgan and Signorelli, 1990). On the other hand the last stage may take the form of "normalization," that is to return to a more sober way of media reporting and imagination, allowing scientific interpretations to be conveyed through the media.

In these studies, the respondents' ideas about biotechnology were assessed with socalled image items about genes and genetically modified organisms, which were found to be relevant in preceding pilot interviews and focus groups. Such examples included the following: "Ordinary tomatoes do not contain genes while genetically modified tomatoes do," "By eating a genetically modified fruit, a person's genes could also become modified" and "Genetically modified animals are always bigger than ordinary ones." If a respondent judged all three items as "true," he or she was considered to find the "image beliefs" plausible, whereas rejecting all three items simultaneously as "incorrect" was scored as scientifically valid knowledge. "Don't know" responses to all three items constituted an "admitted ignorance" score. The databases were Eurobarometer surveys from the years 1996 and 1999.

Figure 1 presents a schematic illustration of the process in time. In the pre-coping phase, that is before a challenging scientific or technological innovation becomes relevant through media agenda setting, we observe a relatively high number of "don't know" responses with items related to image beliefs about the topic. This goes hand in hand with a low frequency of scientifically adequate knowledge. In this phase people tend to admit their ignorance and/or to express that the topic in question is not of any interest to them.

The coping phase is initiated by a rapidly increasing level of media attention signaling societal relevance as depicted by the respective curve in Figure 1. Simultaneously, we observe a sharply reduced level of "don't know" answers. It seems that in contrast to the previous phase, where a stance of ignorance and disinterest appears to be legitimate, in the coping phase the topic attains some personal relevance that prevents respondents from admitting ignorance and disinterest. We interpret this finding as showing that when the novel appears as a frequent topic in personal conversation as well as in public discourse, political controversy and media reporting, people are socially required to adopt an interpretive device that renders the novel intelligible to some extent (Wagner et al., 2002). This resembles to a certain degree the discursive processes postulated in the agenda-setting approach (McCombs, 1981). As discussed before, the construction of the vernacular science understanding of biotechnology may be driven by an intrinsic interest, by a fear of 


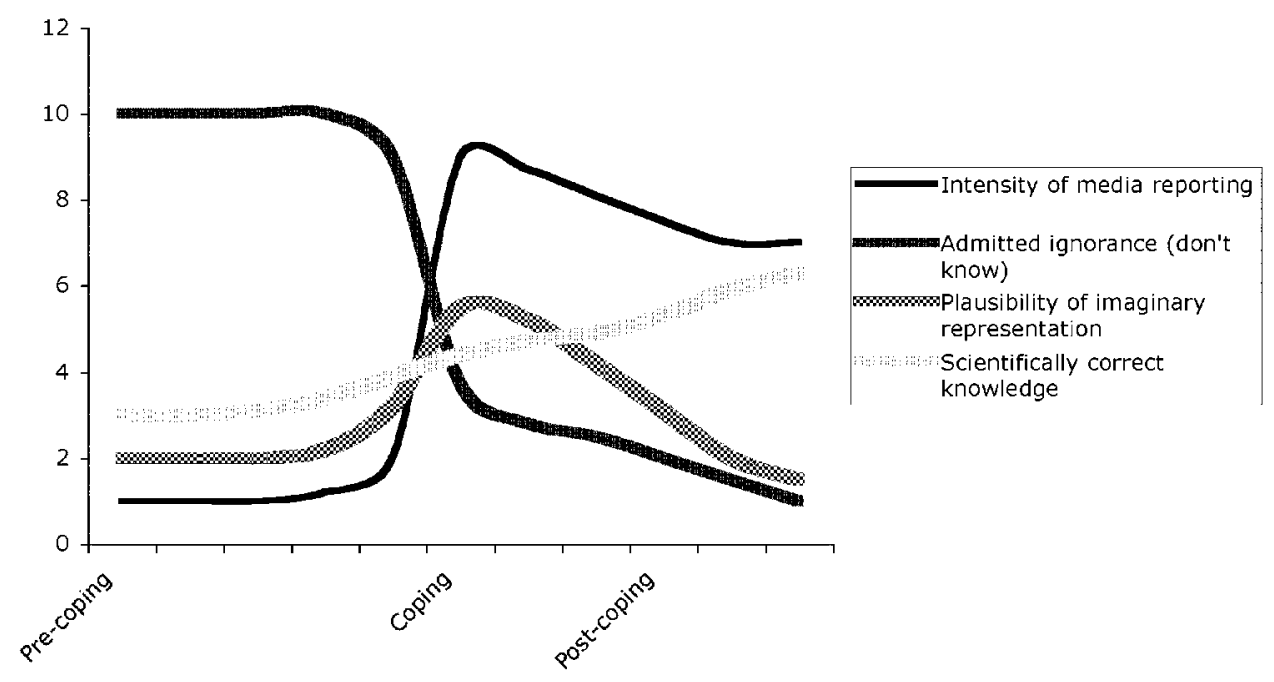

Figure 1. Schematic sketch of processes involved in collective symbolic coping over time (not to scale). (Data from Wagner, Kronberger and Seifert, 2002.)

unfamiliarity, or - and I think this is the most plausible explanation in the present contextby the people's implicit obligation or need to express opinions in conversations and to take position in political debates, when not doing so may entail social punishment.

The question is, what kind of knowledge replaces ignorance? The peak in the curve "plausibility of imaginary representation" as well as the persisting low level of scientifically correct answers indicates that it is a form of knowledge that can best be characterized as "communicative knowledge." In the coping phase, many more people than in the pre-coping phase found "ordinary tomatoes not possessing genes," "genetically modified food infecting its consumer," and "GM animals being bigger than ordinary ones" plausible beliefs once genetic engineering figured as a topic in the media. In interviews this way of thinking is well illustrated in the following statement:

Well, I mean ... we are all living well, and ... we are not experiencing hunger, and ... I don't know why we then still need larger tomatoes . . . it is certainly healthier, if we do this by the normal way ... instead of MIXING SOMETHING TO IT [the vegetables] OR INJECTING SOMETHING ... I don't know. [capitalized words pertain to the image] (Wagner et al., 2002: 332)

In the case of biotechnology, some newspapers reproduced this image half a year later-at least in Austria-by showing a staged photograph where a white-gloved hand holds three nice looking tomatoes and where the other hand applies a syringe containing a red liquid to a tomato (reproduced in Wagner et al., 2002). The metaphor of genetic engineering as introducing some foreign substance, that is genes, into natural organisms, hence, existed on the level of the media as well as of the individuals although the relationship between these levels remains unclear (cf. Ten Eyck, 2005). During the post-coping phase the level of agreement to these items falls ever so slowly and more scientifically valid answers replace "communicative knowledge" answers in the long run and with persisting relevance of the issue. 


\section{Sources for communicative science knowledge}

Communicative knowledge such as the aforementioned "tomato-syringe complex" is the result of a collective symbolic coping process with biotechnology. In our aforementioned study about the introduction of genetic engineering in Austria, during 1996, and in Greece, beginning in 1997 and culminating in 1999, people were under pressure to come to terms with the novel and complex phenomenon of biotechnology that threatened to bring genetically modified food to the supermarket shelves. The media discourse regarding biotechnology became frantic and topics such as crop release experiments, political regulation and the safety of genetically modified food were publicly debated. Lacking the discursive tools for understanding this technology in scientific terms, the publics in both countries were called upon to take positions and express opinions. In order to do this, people needed to find a symbolic handle on the new phenomenon, that is, the public collectively engaged in a process of symbolic coping. The fact that many people ceased to express ignorance in favor of expressing belief in communicative image knowledge has little to do with assimilating scientific knowledge for understanding but reflects the people's prime concern in everyday life, which is: being able to participate in communication and to appear as competent participants in societal discourse. Ignorance was replaced by image and metaphorical representations, which served the communicative purpose sufficiently well. Whether this communicative knowledge was attained in a passive way and without much personal initiative or whether it involved a component of active reasoning and information search is a secondary issue.

Communicative knowledge consists of a series of beliefs, images and metaphors that form a social representation about a topic (Moscovici, 2000). It is the mundane form of thinking about relatively distant and general facts and things that do not directly and materially impinge upon one's personal life (Guerin, 2001: 53). These mundane social representations have sufficient "explanatory power" for everyday understanding and allow people to make themselves understood and to understand others' comments on the topic (cf. Bauer and Gaskell, 1999; Duveen, 1998; Moscovici, 2000; Wagner and Hayes, 2005).

Work on the public perception of biotechnology, shows how media and people creatively apply existing literary, popular, and other fictional cultural resources in their attempts to understand and communicate ideas and concepts from the new biological science in a way that makes sense (cf. Christidiou et al., 2004; Einsiedel et al., 2002; Nerlich et al., 1999, 2000). Sources for metaphorical understanding are pre-existing elements of knowledge that allow one to "anchor" new phenomena and to draw inferences by analogy (cf. Castro and Gomes, 2005). The fact that this kind of background knowledge does not correspond with scientific nomenclature is-among many other reasons (cf. Kronberger et al., 2001; Wynne, 1996) - the fuel for widespread resistance against a new technology (Gaskell and Allum, 2001).

Analogous to linguistics, where "vernacular" means "colloquial language, conversational language, common parlance, demotic, lay terms" (Oxford and American Dictionary as implemented in Apple's Mac OS 10.4), I propose calling this widely distributed form of popular understanding of science "vernacular science." Vernacular science knowledge is different from scientific understanding among knowledgeable lay publics, as is often found with scientifically interested sub-publics and amateur scientists. Bird watchers, amateur astronomers and other people with a genuine interest in scientific insight exhibit a much more accurate form of knowledge about their area of expertise than does the average person. Additionally, concerned sub-publics with a stake in a particular technological issue that materially affects them-for example sheep farmers with a history of damage done to their 
flocks by nearby nuclear plants-might develop expertise that is more relevant to their problem than is scientific expertise deriving from laboratory research (Wynne, 1996).

The limitations of vernacular science knowledge do not indicate a deficit when aligned with its proper criterion of validity: enabling communication on an everyday level, following television news and newspaper reports and responding to one's neighbor's casual remark about "Dolly, the clone," for example. Under this criterion, vernacular science is neither superstitious nor wrong but serves a purpose different from genuine popularized science. In modern societies, the way from scientific innovation to its public understanding does not go straight from ignorance to scientific literacy via top-down enlightenment. It comes about in the long run, when scientific development has been milled through schools, academic teaching and learning, and well-informed media reporting. Vernacular science knowledge is an intermediate stage before understanding in more scientifically relevant terms might come about. In this stage, the public compensates for a lack of scientific literacy by anchoring the new in whatever images and metaphors are at their disposal. At this stage, the people's motivation to consult textbooks as the canonical manifestation of science is probably very low. Social Representation Theory acknowledges the local validity and communicative functions of whatever images, beliefs, metaphors or representations people produce and collectively "validate" in their attempt to come to communicable terms with the modern world.

\section{The social structure of metaphorical and image knowledge}

Medical science certainly counts as the most popular of all scientific domains owing to its relevance for health and well-being. It is a versatile domain for use as a reservoir for metaphorical anchoring as shown in the syringe metaphor illustrating the afore-discussed vernacular understanding of genetic engineering. But vernacular medical knowledge is itself structured in a metaphorical way as shown in the following study about conception and fertilization (Wagner et al., 1995).

Fertilization is a natural process that is described in biomedical terms of anatomy, cytology, physiology, endocrinology etc. In scientific understanding, it is a process stirred by complex biological relationships between gametes and ovum within the chemical ecology of vagina, uterus, Fallopian tube, and ovary (Austin and Short, 2003). The fundamental event is the meeting and merging of two entities, the sperm and the ovum. This fact has been known in medical science since the end of the eighteenth century (Darmon, 1977) and nowadays is common knowledge in the industrialized world.

Hence, people with a standard level of schooling know about the two entities, sperm and ovum, involved in procreation. Does this mean, though, that the average person thinks about these entities in terms of biological cells possessing biological attributes or does he or she elaborate a metaphorical image in order to make his or her basic understanding meet communicative needs?

We studied this image in an experiment and expected that people would use an anthropomorphic metaphor in order to make the natural process intelligible. This metaphor is popular in public advertising and nicely exemplified in Figure 2.

The experiment involved testing the participants' preference for a variety of metaphorical comparisons that gave sperms and ova different roles. The comparisons referred either to gender roles (e.g. "The role of the sperm towards the egg cell during conception corresponds to the role of men courting a woman," etc.), or to non-human domains (e.g. "The role of the ovum towards the sperms resembles that of a cat catching a mouse" etc.). 


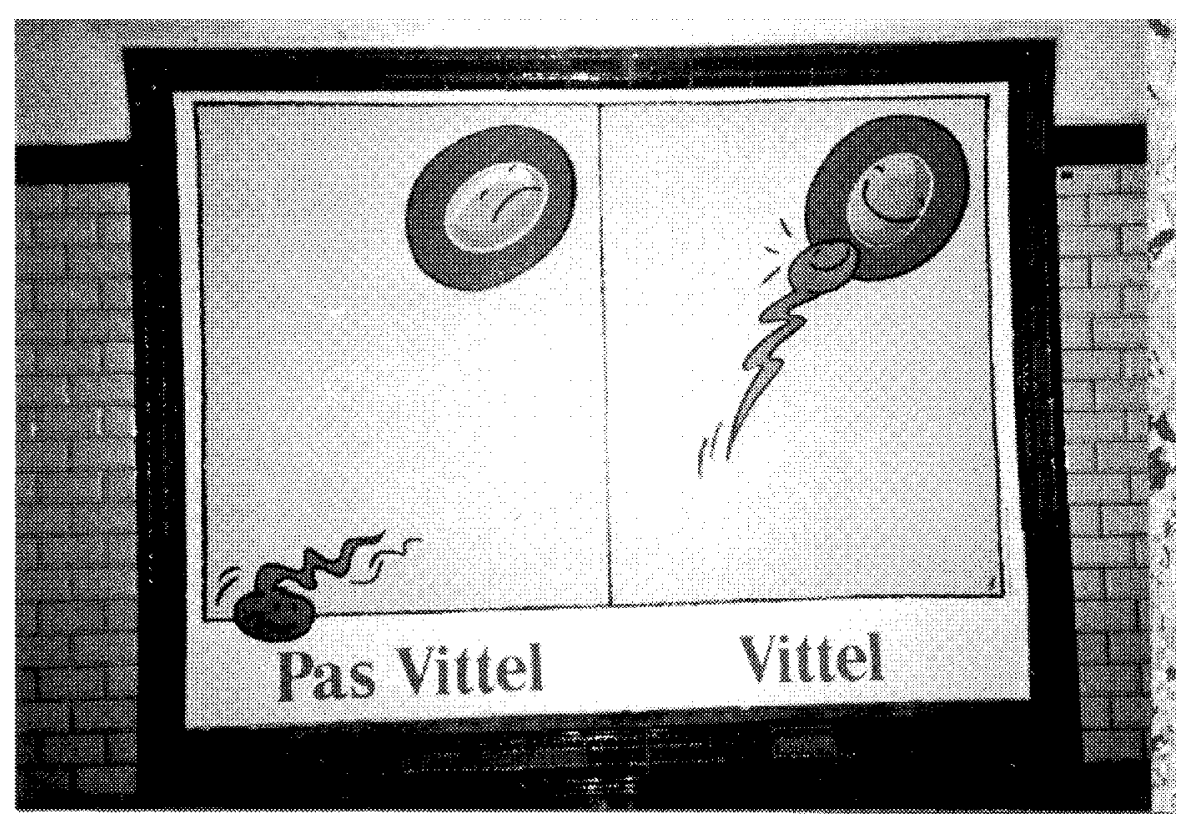

Figure 2. Advertising campaign for a mineral water in Paris, 1993, alluding to an anthropomorphic metaphor of sperm and ovum. (@ Wolfgang Wagner.)

This independent variable was crosscut by a second factor in which either the active role of the ovum (not a gender role stereotype) or of the sperm (gender role stereotype) was emphasized. In addition, participants were asked to judge characteristics of the two cells on polarity scales, half of which comprised adjectives related to gender stereotypes (big-small, weak-strong, submissive-dominant, etc.) while the other half were gender neutral (important-unimportant, negative-positive, dumb-intelligent, etc.) (Wagner et al., 1995).

The result showed that people preferred metaphors where the "behaviors" of sperm and ovum were sex-role congruent and anthropomorphic. They attributed activity to the sperms and passivity to the ovum. Note that attributing activity to the sperms and passivity to the ovum is not in accord with scientific medical textbooks and literature, which picture these cells as being largely transported by cilial movement and where the ovum-via chemical communication-plays a key role in orienting the sperms' movement (e.g. Austin and Short, 2003).

Additionally — and as an effect of metaphorical entailment (Lakoff, 1987) — the sperm and ovum cells were judged to possess gender stereotypical attributes: sperms were perceived as being stronger, harder, and more dominant than ova. An important part of the findings was a significant effect of local culture. Participants subscribing to conservative gender-roles in everyday life judged the sperm's characteristics to be more stereotypically male and the ovum's attributes to be more female (i.e. weaker, softer, more passive and more submissive etc.) than gender-role liberals. This cultural effect was independent of the sex of participants (Figure 3) (Wagner et al., 1995).

The essence of these results was replicated in a study where some participants read a scientific textbook paragraph about sperms and ova, which they had to relate to other participants in a serial reproduction chain. The original scientific article gave a balanced scientific representation of the biological cells' roles and functions. After five generations of 


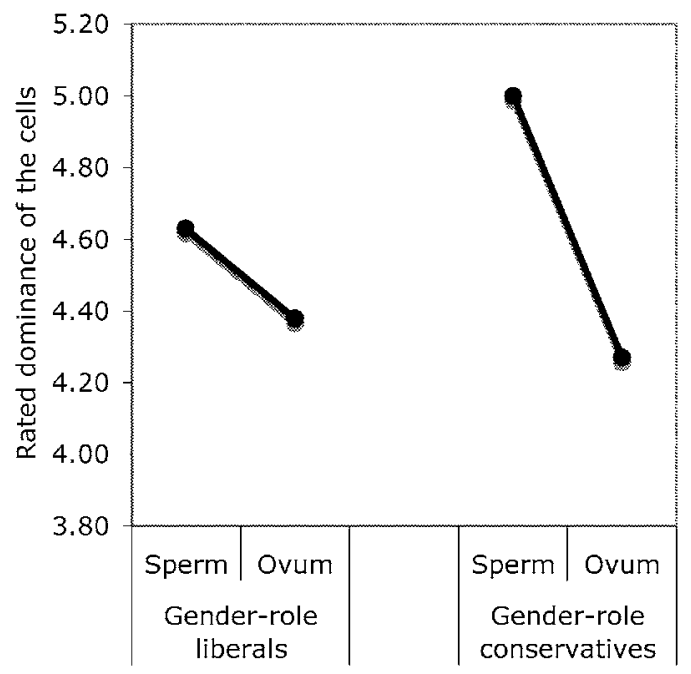

Figure 3. Degree of "dominance" attributed to sperms and ova. (Data from Wagner, Elejabarrieta and Lahnsteiner, 1995.)

serial reproduction, however, the participants in the experiment gave the sperm active subject status in sentences, rising from about 50 percent to 85 percent and reproductions that referred to the sperm as "traveling" rose from zero to about 60 percent (Bangerter, 2000).

Consistently, these findings do not strike my students as particularly surprising because they, and indeed the majority of us, adhere to this image. It is an example of a deeply entrenched scientific myth that is perpetuated in school education and media programs, although it is based on outdated and vastly simplified scientific information. The only reason for its existence is its imaginary and communicative force. By comparing the characteristics and behavior of natural cells with men and women in social life, the process of fertilization becomes immediately intelligible as a mirror image of social life and the abstract entities of sperm and ovum cells become converted into imaginable entities with social attributes. The cells, invisible to the unaided eye, become part of our everyday world and this knowledge serves a communicative purpose. The image is dominant in much of advertising as any reader can certainly testify. It is also "good to talk" with, as reflected in a comment by an eminent Spanish professor of gynecology in a class during the 1960s, who said that "Contra esperma vigoroso no hay óvulo que resista" ("There is no ovum that resists a vigorous sperm"). ${ }^{2}$ The author of a newspaper story about "subzonal insemination," whereby a single sperm is artificially injected into an ovum, referred to the same representation when he titled his story "Le viol de l'ovule" ("The rape of the ovum") (Nau, 1994).

\section{Discursive polyphasia and local evidence}

There is an interesting corollary to the existence of communicative knowledge: cognitive or discursive polyphasia. In research about the contemporary understanding of mental illness in an Indian city's middle-class, we found that traditional Indian representations of mental illness and healing frequently coexist with logically contradictory knowledge about modern psychiatry in one and the same person; the former representations were likely to be expressed in family settings, the latter in the public domain (Wagner et al., 2000). 
Common sense and everyday thinking frequently embrace representations that carry contradictory meanings. Such contradictions are usually not disturbing so long as each representation is locally consistent and so long as they are not simultaneously expressed in discourse (Wagner and Hayes, 2005). People do not live in a single homogeneous world, but in many worlds, each of which requires its own distinct form of discourse and thought. It is in the context of different social worlds that holding "contradictory" representations makes sense. Representations are not primarily reproductions of facts in the world, but above all, they are elaborations for social groups serving to maintain the stability of their local world. In this view, knowledge and representations are bound to social contexts, that is to groups and their life-worlds and to situations and events occurring in these worlds, that demand specific forms of thinking and talking. Apparent contradictions between representations in common-sense thinking can be explained if their situated use and communicative purpose are taken into account.

Finally, there is the question of what does it mean to justify vernacular knowledge by its communicative purpose and further, can this knowledge be called rational? First, we should be aware that "the [substantive] rationality of beliefs concerns the relation between the belief and the available evidence, not the relation between the belief and the world" (Elster, 1983: 16). Scientific knowledge, for example, is based on the evidence provided by empirical methods of data collection and on the rules of rational interpretation that are supposedly guaranteed by peer review. The essence of this manner of providing evidence for scientific facts lies in probing external reality through material means and in the surprising efficiency in shaping reality to mankind's desire. Through this definition of truth, modern science has achieved its present state of the art.

In general, any locally accepted definition of what constitutes evidence for beliefs circulating in social groups has historical, cultural and social roots and is, therefore, a socially shared belief itself. Evidence for communicative and vernacular knowledge is tightly linked to their "aesthetic" or cultural appeal. A piece of social knowledge is evident insofar as it can be used or asserted with the warrant that co-members of a group react in an understanding way (Habermas, 1985). Warranted assertibility of an image or idea means that whenever a person enters into discourse with another, a consensus about the assertion can be reached, presupposing the goodwill to do so. The essence of this manner of providing evidence for social knowledge lies in its self-referent and mutual use in discourse and action and their intelligibility by others. In everyday life, there is no outside reference other than the pattern of interactions and of discursive acts unfolding in a social setting. This also means that social knowledge is always situated and related to specific times, places and social groups as illustrated by the phenomenon of cognitive polyphasia.

It needs no mention that modern society consists of a multitude of partly overlapping social groups, milieus, and life-worlds. In each sub-unit, people engage in activities and tasks, which either require or historically received a local definition of what constitutes genuine evidence for the representations employed or brought to bear on particular situations. Everyday life for the majority of people in our societies at present is structured such that vernacular representations of science suffice to fulfill the criteria of socially successful discourse.

\section{Conclusions}

The present paper argues in favor of a more generous interpretation of the public's understanding of science or lack thereof. People inhabiting everyday life-worlds, who are far 
from science in their everyday chores, legitimately employ validity criteria for their background knowledge that are at odds with scientific standards. This is not a deficit as long as the dominant criterion is warranted communication and social belonging maintained by participation in conversations. Vernacular science knowledge in contemporary societies is the outcome of recycling scientific and technological news as items of discourse. Only quite rarely would people feel the need for a veridical representation of a scientific fact.

By focusing on the needs and communication behaviors of "normal" people, Social Representation Theory offers a comprehensive theoretical framework for understanding common sense and public knowledge of science in relation to communication and media processes in modern societies, whether it is about media unwittingly tailoring their reporting about, and metaphorical framing of, the so-called "Mozart effect" according to the educational needs of US states: the more the educational system of a state was in financial trouble, the more the local media re-reported the Mozart effect as supposedly making babies and children more intelligent (Bangerter and Heath, 2004); the French public in the 1950s assimilating the psychological theory of psychoanalysis where different sectors of the public and the press elaborated different versions of the concept depending on the sector's social background (Moscovici, 1976); the public understanding of viral diseases and their risks (Joffe and Haarhof, 2002; Joffe and Lee, 2004; Washer, 2004); or the cognitive elaboration and cultural communication of images of monstrosity of genetically modified animals by individuals and media (Wagner et al., 2006, submitted).

The public's understanding of science is embedded in the web of individual, collective and political processes of communication. Public discourse makes science more than and, at the same time, less than a stripped down version of the original. In the present model, the route scientific information takes from the laboratories to the public does not resemble an error-prone conduit but more a meat grinder mincing the chunks of scientific "meat" and seasoning it with various cultural and imaginary spices. Vernacular and communicative knowledge resembles science knowledge as much as a hamburger resembles the original filet; and, just as a hamburger is tastier than the original unseasoned meat, everyday science is popular and good to talk about even though it reflects little if anything of its original scientific shape.

\section{Acknowledgement}

The author gratefully acknowledges helpful comments by Helge Torgersen on an earlier draft of this paper.

\section{Notes}

1 In contrast to questionnaire studies, the method of time sampling allows a reliable estimate of time spent in situations. Note that these studies were conducted about two decades ago.

2 Personal communication by Carmen Huici, Madrid.

\section{References}

Austin, C.R. and Short, R.V., eds (2003) Reproduction in Mammals. Cambridge: Cambridge University Press.

Bangerter, A. (1995) "Rethinking the Relation between Science and Common Sense: a Comment on the Current State of Social Representation Theory" [online], Papers on Social Representations 4: 61-78, URL: http:// www.psr.jku.at/

Bangerter, A. (2000) "Transformation between Scientific and Social Representations of Conception: the Method of Serial Reproduction," British Journal of Social Psychology 39: 521-36.

Bangerter, A. and Heath, C. (2004) "The Mozart Effect: Tracking the Evolution of a Scientific Legend," British Journal of Social Psychology 43(4): 605-23. 
Bauer, M. (1993) "Francophone Research on Popular(izing) Science: a Commented Bibliography, 1960-1992," Unpublished manuscript, Maison des Sciences de l'Homme, Paris.

Bauer, M. (2002) "Controversial Medical and Agri-food Biotechnology: a Cultivation Analysis," Public Understanding of Science 11: 93-111.

Bauer, M. and Gaskell, G. (1999) "Towards a Paradigm for Research on Social Representations," Journal for the Theory of Social Behavior 29: 163-86.

Bauer, M. and Gaskell, G., eds (2002) Biotechnology_the Making of a Global Controversy. Cambridge: Cambridge University Press.

Bourdieu, P. (1979) La distinction. Critique sociale du jugement [Distinction: a social critique of the judgment of taste]. Paris: Les éditions de minuit.

Brandstätter, H., Barthel, E. and Fünfgelt, V. (1984) "Beruf 'Hausfrau': Eine psychologische Studie mit dem Zeitstichproben-Tagebuch" ["Profession 'housewife': a psychological study with the time sampling-diary"], in R. Blum and M. Steiner (eds) Aktuelle Probleme der Marktwirtschaft aus Einzel- und gesamtwirtschaftlicher Sicht. Berlin: Duncker \& Humblot.

Castro, P. and Gomes, I. (2005) "Genetically Modified Organisms in the Portuguese Press: Thematisation and Anchoring," Journal for the Theory of Social Behavior 35: 1-18.

Christidiou, V., Dimopoulos, K. and Koulaidis, V. (2004) "Constructing Social Representations of Science and Technology: the Role of Metaphors in the Press and the Popular Scientific Magazines," Public Understanding of Science 13: 347-62.

Darmon, P. (1977) Le mythe de la procreation à l'âge baroque. Paris: J.-J. Pauvert.

Durant, J., Evans, G.A. and Thomas, G.P. (1989) "The Public Understanding of Science," Nature 340: 11-14.

Duveen, G. (1998) “The Psychological Production of Ideas: Social Representations and Psychologic," Culture and Psychology 4: 369-86.

Einsiedel, E., Allansdottir, A., Allum, N., Bauer, M., Berthomier, A., Chatjouli, A., Cheveigné, S., Downey, R., Gutteling, J.M., Kohring, M., Leonarz, M., Manzoli, F., Olofsson, A., Przestalski, A., Rusanen, T., Seifert, F., Stathopoulou, A. and Wagner, W. (2002) "Brave New Sheep-the Clone Named Dolly," in M. Bauer and G. Gaskell (eds) Biotechnology—the Making of a Global Controversy, pp. 313-47. Cambridge: Cambridge University Press.

Elias, N. (1978) "Zum Begriff des Alltags," in K. Hammerich and M. Klein (eds) Materialien zur Soziologie des Alltags [Materials on the sociology of everyday], pp. 22-9. Opladen: Westdeutscher Vlg.

Elster, J. (1983) Sour Grapes: Studies in the Subversion of Rationality. Cambridge: Cambridge University Press.

Gamson, W.A. and Modigliani, A. (1989) "Media Discourse and Public Opinion on Nuclear Power: a Constructionist Approach," American Journal of Sociology 95: 1-37.

Gaskell, G. and Allum, N. (2001) "Sound Science, Problematic Publics? Contrasting Representations of Risk and Uncertainty," Notizie di Politeia 17: 13-25.

Gaskell, G. and Bauer, M., eds (2001) Biotechnology 1996-2000: The Years of Controversy. London: The National Museum of Science and Industry.

Gaskell, G., Allansdottir, A., Allum, N., Fischler, C., Hampel, J., Jackson, J., Kronberger, N., Mejlgaard, N., Revuelta, G., Schreiner, C., Stares, S., Torgersen, H. and Wagner, W. (2006) Europeans and Biotechnology in 2005: Patterns and Trends. A report to the European Commission's Directorate General for Research. London: London School of Economics and Political Science.

Geertz, C. (1983) Dichte Beschreibung. Beiträge zum Verstehen kultureller Systeme [Thick description: Contributions to understanding cultural systems]. Frankfurt: Suhrkamp.

Guerin, B. (1997) "The Social Context of Communication: Communicative Power as Past and Present Social Consequences," in J. Owen (ed.) Context and Communication Behavior, pp. 133-79. Reno, NV: Context Press.

Guerin, B. (2001) "Replacing Catharsis and Uncertainty Reduction Theories with Descriptions of Historical and Social Context," Review of General Psychology 5: 44-61.

Habermas, J. (1985) Theorie des kommunikativen Handelns Band 1: Handlungsrationalität und gesellschaftliche Rationalisierung. Frankfurt: Suhrkamp.

Irwin, A. and Wynne, B., eds (1996) Misunderstanding Science: The Public Reconstruction of Science and Technology. Cambridge: Cambridge University Press.

Joffe, H. and Haarhof, G. (2002) "Representations of Far-flung Illnesses: the Case of Ebola in Britain," Social Science and Medicine 54: 955-69.

Joffe, H. and Lee, N.Y.L. (2004) "Social Representation of a Food Risk: the Hong Kong Avian Bird Flu Epidemic," Journal of Health Psychology 9(4): 517-33.

Jones, E.E. and Gerard, H.B. (1967) Foundations of Social Psychology. New York: Wiley.

Kempton, W. (1986) “Two Theories for Home Heat Control," Cognitive Science 10: 75-90. 
Kirchler, E. (1989) "Everyday Life Experiences at Home: an Interaction Diary Approach to Assess Marital Relationships," Journal of Family Psychology 2: 311-36.

Kronberger, N., Dahinden, U., Allansdottir, A., Seger, N., Pfenning, U., Gaskell, G., Allum, N., Rusanen, T., Montali, L., Wagner, W., Cheveigné, S., Diego, C. and Mortensen, A. (2001) “The Train Departed Without Us': Public Perceptions of Biotechnology in Ten European Countries," Notizie di Politeia 17: 26-36.

Lakoff, G. (1987) Women, Fire and Dangerous Things. Chicago, IL: University of Chicago Press.

McCombs, M.E. (1981) “The Agenda-Setting Approach,” in D.D. Nimmo and K.R. Sanders (eds) Handbook of Political Communication, pp. 121-40. London: SAGE.

March, J.G. and Olson, J.P. (1986) "Garbage Can Models of Decision Making in Organizations," in J.G. March and R. Weissinger-Baylon (eds) Ambiguity and Command: Organizational Perspectives on Military Decision Making, pp. 11-35. Cambridge: Ballinger.

Matthes, J. and Schütze, F. (1981) "Alltagswissen, Interaktion und gesellschaftliche Wirklichkeit," in Arbeitsgruppe Bielefelder Soziologen (ed.) Alltagswissen, Interaktion und gesellschaftliche Wirklichkeit [Everyday knowledge, interaction and social reality], pp. 11-52. Opladen: Westdeutscher Verlag.

Morgan, M. and Signorelli, N. (1990) Cultivation Analysis. Newbury Park, CA: SAGE.

Moscovici, S. (1963) "Attitudes and Opinions," Annual Review of Psychology 14: 231-60.

Moscovici, S. (1976) La psychanalyse son image et son public. Paris: Presses Universitaires de France.

Moscovici, S. (1984) "The Phenomenon of Social Representations," in R. Farr and S. Moscovici (eds) Social Representations, pp. 3-69. Cambridge: Cambridge University Press.

Moscovici, S. (1992) "The Psychology of Scientific Myths," in M. v. Cranach, W. Doise and G. Mugny (eds) Social Representations and the Social Bases of Knowledge, pp. 3-9. Lewiston, NY: Hogrefe \& Huber.

Moscovici, S. (2000) Social Representations: Explorations in Social Psychology, trans. G. Duveen. Cambridge: Polity Press.

Nau, J.-Y. (1994) "Le viol de l'ovule" [“The rape of the ovum”], Le Monde Sunday 26 and Monday 27 June, pp. 1, $10 \mathrm{f}$.

Nerlich, B., Clarke, D.D. and Dingwall, R. (1999) “The Influence of Popular Cultural Imagery on Public Attitudes towards Cloning," Sociological Research Online 4(3), URL: http://www.socresonline.org.uk/4/3/nerlich. html

Nerlich, B., Clarke, D.D. and Dingwall, R. (2000) "Clones and Crops: the Use of Stock Characters and Word Play in Two Debates about Bioengineering," Metaphor and Symbol 15: 223-39.

Sprondel, W.M. (1979) “"Experte' und 'Laie': Zur entwicklung von Typenbegriffen in der Wissenssoziologie,” in W.M. Sprondel and R. Grathoff (eds) Alfred Schütz und die Idee des Alltags in den Sozialwissenschaften, pp. 140-54. Stuttgart: Luke.

Sturgis, P. and Allum, N. (2004) "Science in Society: Re-evaluating the Deficit Model of Public Attitudes," Public Understanding of Science 13: 55-74.

Ten Eyck, T.A. (2005) "The Media and Public Opinion on Genetics and Biotechnology: Mirrors, Windows or Walls?," Public Understanding of Science 14: 305-16.

Wagner, W. and Gerard, H.B. (1983) "Similarity of Comparison Group, Opinions about Facts and Values, and Social Projection," Archives of Psychology 135: 313-24.

Wagner, W. and Hayes, N. (2005) Everyday Discourse and Common Sense: The Theory of Social Representations. Basingstoke: Palgrave-Macmillan.

Wagner, W., Elejabarrieta, F. and Lahnsteiner, I. (1995) "How the Sperm Dominates the Ovum: Objectification by Metaphor in the Social Representation of Conception," European Journal of Social Psychology 25: 671-88.

Wagner, W., Duveen, G., Verma, J. and Themel, M. (2000) "II Have Some Faith and at the Same Time I don't Believe in it': Cognitive Polyphasia and Culture Change," Journal of Community and Applied Social Psychology 10: 301-14.

Wagner, W., Kronberger, N. and Seifert, F. (2002) "Collective Symbolic Coping with New Technology: Knowledge, Images and Public Discourse," British Journal of Social Psychology 41: 323-43.

Wagner, W., Kronberger, N., Berg, S. and Torgersen, H. (2006) "The Monster in the Public Imagination," in G. Gaskell and M. Bauer (eds) Genomics and Society: Legal, Ethical and Social Dimensions, pp. 150-68. London: Earthscan.

Wagner, W., Kronberger, N., Nagata, M. and Sen, R. (submitted) "The Monstrosity Effect across Cultures: Affective Entailments of Cognizing Violations of Animal Kind Essence."

Washer, P. (2004) "Representations of SARS in the British Newspapers," Social Science and Medicine 59(12): 2561-71.

Wynne, B. (1996) "Misunderstood Misunderstandings: Social Identities and Public Uptake of Science," in A. Irwin and B. Wynne (eds) Misunderstanding Science: The Public Reconstruction of Science and Technology, pp. 19-46. Cambridge: Cambridge University Press. 


\section{Author}

The author is professor of social psychology at the Johannes Kepler University of Linz, Austria. His recent research interests include structures and processes of social and cultural knowledge, public understanding of science and technology, particularly biotechnology and genetics, culture change, and social representation theory. Correspondence: Department of Social and Economic Psychology, Johannes Kepler Universität, Altenbergerstrasse 69, 4040 Linz, Austria; e-mail: w.wagner@jku.at 